\title{
KERIPIK TERONG SEBAGAI ALTERNATIF OLAHAN HASIL PERTANIAN DUSUN PONDOK, SENDANG, JAMBON, PONOROGO
}

\author{
Moh. Faizin, Dwi Agung Wahyu Saputra \\ Fakultas Ekonomi dan Bisnis Islam, IAIN Ponorogo \\ Email: faiziniainpo@gmail.com
}

\begin{abstract}
The people of Sendang Village, Jambon Subdistrict, Ponorogo Regency, especially Pondok Country, were mostly farmers. Some farmers in Pondok Country grew vegetables, especially eggplant. In general, eggplant was only intercropping plant or crop interlude in some part of the land they plant. So far, the farmers had suffered losses because the eggplants' prices tended to be unstable. Therefore, this community service activity was carried out to empower the people of Pondok Country in social entrepreneurship activities to solve the problems that existed in the community environment. The community service team provided training to the community by making alternative processed products in the form of eggplant chips. This activity consisted of three stages, namely preparation, implementation and evaluation. At the implementation stage, the activities carried out in the form of training in making eggplant chips. The training was held in one of the houses of the residents. The result of this activity was the formation of social entrepreneurship growing in the community environment with products in the form of processed eggplant chips that can increase the community income. The processing of eggplants into chips could also minimize the farmers' losses because the chips were not stale easily and the prices became stable.
\end{abstract}

Keywords: Empowerment, social entrepreneurship, eggplant chips

\begin{abstract}
Abstrak: Masyarakat Desa Sendang Kecamatan Jambon Kabupaten Ponorogo khususnya Dusun Pondok rata-rata bermatapencarian sebagai petani. Sebagian petani di Dusun Pondok menanam sayuran khususnya terong. Secara umum tanaman terong tersebut hanya merupakan tanaman tumpang sari atau tanaman selingan pada sebagian lahan yang mereka tanami. Selama ini petani mengalami kerugian karena harga terong yang cenderung tidak stabil. Oleh sebab itu, kegiatan pengabdian masyarakat ini dilakukan dengan tujuan untuk memberdayakan masyarakat Dusun Pondok dalam kegiatan kewirausahaan sosial untuk menyelesaikan permasalahan yang ada di lingkungan masyarakat tersebut. Tim pengabdian masyarakat memberikan pelatihan kepada masyarakat sekitar dengan membuat produk olahan alternatif berupa keripik terong. Kegiatan ini terdiri dari tiga tahap yaitu persiapan, pelaksanaan dan evaluasi. Pada tahap pelaksanaan, kegiatan yang dilakukan berupa pelatihan pembuatan keripik terong. Pelatihan dilaksanakan di salah satu rumah warga. Hasil dari kegiatan ini adalah terbentuknya kewirausahaan sosial yang tumbuh di lingkungan masyarakat dengan produk berupa olahan keripik terong yang mampu menambah penghasilan masyarakat. Adanya pengolahan terong menjadi keripik juga dapat meminimalisir kerugian petani karena keripik tidak mudah basi dan hargaya lebih stabil.
\end{abstract}




\section{PENDAHULUAN}

Indonesia sebagai negara agraris menjadikan sektor pertanian menjadi sangat penting dan strategis. Mengingat pada sektor pertanian masih memberikan lapangan pekerjaan sebagian besar penduduk khususnya yang berada di kawasan pedesaan (Sadono, 2008). Kabupaten Ponorogo merupakan kabupaten di Jawa Timur dengan topografi wilayah yang cukup bervariasi. Wilayah kabupaten Ponorogo sebagian besar yaitu $79 \%$ berada di ketinggian kurang dari $500 \mathrm{~m}$ di atas permukaan laut, $14,4 \%$ berada diantara 500 hingga $700 \mathrm{~m}$ di atas permukaan laut dan sisanya sebesar 5,9\% berada pada ketinggian di atas $700 \mathrm{~m}$ diatas permukaan laut. Hal ini menjadikan Kabupaten Ponorogo sebagai daerah dataran rendah dan mempunyai iklim tropis yang mengalami dua musim, musim kemarau dan musim penghujan (BPS, 2019).

Kondisi topografi kabupaten ponorogo yang umumnya dataran rendah, menjadikan mayoritas penduduknya bermatapencarian sebagai petani. Secara umum petani di Ponorogo menanam tanaman palawija (padi, kedelai dan jagung). Masyarakat Desa Sendang khususnya masyarakat Dusun Pondok rata-rata bermatapencarian sebagai petani. Permasalahan umum yang ada di masyarakat adalah pendapatan yang relatif rendah, sehingga perlu sebuah upaya dalam meningkatkan pendapatan di masyarakat desa (Rahmawati, et al, 2018). Senada dengan pendapat Rahmawati dkk. Bahwa dalam menghadapi permasalahan para petani, diperlukan sebuah alternatif pemecahan masalah dengan membuat sebuah pelatihan pembuatan makanan yang menggunakan bahan dasar yang mudah dijumpai di daerah yang bersangkutan dengan maksud untuk mendapatkan keuntungan dan peningkatan taraf hidup keluarga (Wiyanto, 2019). Diantara para petani di Dusun Pondok hanya sebagian dari petani yang menanam sayuran khususnya terong. Dan secara umum tanaman terong tersebut hanya merupakan tanaman tumpang sari ataupun tanaman selingan pada sebagian lahan yang mereka tanami. Ketika mewawancarai warga, didapati bahwa warga cenderung enggan untuk menanam terong di lahan yang mereka miliki. Hal ini dikarenakan harga terong di pasaran yang cenderung tidak stabil. Pada saat tertentu harga cukup tinggi di pasaran, ketika semacam itu petani diuntungkan, tetapi tidak jarang harga anjlok jauh dibawah perkiraan. Akibatnya para petani rugi dan enggan melanjutkan untuk menanam terong kembali. Ketika hal semacam itu terjadi, terong hasil panen hanya bisa dimanfaatkan oleh petani untuk kebutuhan sayur sendiri ataupun dibagikan kepada tetangga sekitar.

Permasalahan tidak stabilnya harga terong menjadi lebih pelik lagi, manakala para petani dan umumnya masyarakat banyak yang tidak mengetahui tentang manfaat dan kandungan yang terdapat pada buah terong untuk kesehatan manusia. Masyarakat secara umum kurang menyadari bahwa untuk hidup sehat manusia tidak hanya memerlukan protein dan kalori, tetapi juga vitamin dan mineral yang kaya dan terkandung dalam sayur-sayuran dan buah. Pola dan perilaku konsumsi ini dipengaruhi oleh berbagai faktor antara lain kemampuan ekonomi masyarakat, ketersediaan dan pengetahuan akan manfaat buah dan sayuran. Untuk itu diperlukan upaya dalam meningkatkan konsumsi buah dan sayuran yang tidak hanya berupa tersedianya sarana dan prasarana tetapi juga upaya perubahan perilaku dan sikap di masyarakat melalui penyuluhan dan sosialisasi dan promosi yang lebih intensif tentang manfaat mengkonsumsi buah dan sayur (Aswatini, Noveria, \& Fitranita, 2008).

Berangkat dari permasalahan ini maka diperlukan sebuah langkah dalam 
upaya peningkatan kesejahteraan penduduk pedesaan. Peningkatan kesejahteraan masyarakat tidak bisa lepas dari pembangunan masyarakat. Pergeseran pemahaman atau paradigma dalam pembangunan masyarakat yang menekankan pentingnya energi sosial yang berupa modal sosial atau modal kultural. Modal sosial sendiri diartikan sebagai segala potensi yang dapat dihasilkan dari segala perilaku interaksi yang dilakukan antar individu atau masyarakat yang mampu mendatangkan manfaat atas dasar nilai, norma dan komitmen (Tohani, Sumarno, \& Suryono, 2015).

Upaya peningkatan perekonomian masyarakat dilakukan dengan cara menumbuhkan embrio social entrepreneurship (kewirausahaan sosial). Kewirausahaan sosial diartikan sebagai upaya penerapan dan upaya menciptakan nilai social yang karakteristiknya diwarnai oleh factor inovasi dalam mengatasi beragam permasalahan sosial yang dihadapi masyarakat (Yaumidin, 2016). Kewirausahaan sosial melihat masalah sebagai peluang dalam membentuk sebuah model bisnis yang baru yang diharapkan mampu bermanfaat bagi masyarakat yang ada di sekitarnya (Utomo, 2015).

Terdapat perbedaan antara konsep social entrepreneurship (kewirausahaan sosial) dengan business entrepreneurship (kewirausahaan biasa), perbedaan tersebut terletak pada bahwa business entrepreneurship walaupun memiliki tujuan untuk mendorong kegiatan kewirausahaan akan tetapi cenderung untuk mengejar keuntungan ataupun memperkaya diri sendiri. Sedangkan pada social entrepreneurship apabila mendapatkan keuntungan dalam kegiatan dan aktifitas ekonomi, maka kekayaan yang didapat tersebut untuk menolong masyarakat atau komunitas yang diberdayakan. Perbedaan yang lain terkait parameter keberhasilan dalam berwirausaha. Kewirausahaan biasa mengukur keberhasilan usaha dari sisi kinerja keuangan yang dihasilkan. Berbeda dengan kewirausahaan sosial mengukur keberhasilan dari sisi tingkat nilai-nilai sosial (social value) yang dihasilkan.

Senada dengan pendapat tersebut, (Fitria, 2018) memberikan gambaran perbedaan antara kewirausahaan sosial dan kewirausahaan biasa sebagai berikut:

(1) Motivasi atau misi

Kewirausahaan biasa bertujuan untuk menguntungkan diri sendiri, berbeda dengan kewirausahaan sosial yang bertujuan untuk fokus pada meningkatnya kesejahteraan bersama dan pengembangan masyarakat secara umum.

(2) Identifikasi masalah yang diselesaikan.

Kewirausahaan

biasa mengidentifikasi permasalahan yang berasal dari keinginan pasar, misalnya dari jenis produk atau tren yang saat ini banyak diminati oleh pasar. Sementara kewirausahaan sosial umumnya mengidentifikasi permasalahan yang berawal dari adanya persoalan yang berkembang di masyarakat untuk ditindaklanjuti dan diselesaikan. Berangkat dari permasalahan yang ada diubah menjadi peluang yang dapat menyelesaikan permasalahan di masyarakat tersebut untuk kemanfaatan bersama.

(3) Identifikasi peluang

Sebuah kesempatan dapat diidentifikasi dalam konteks sosial perlu ada hal yang diperhatikan; Pertama, pemecahan masalah harus dianggap sebagai domain yang resmi untuk aktivitas kewirausahaan. Kedua, agar bermanfaat bagi masyarakat maka usaha yang dilaksanakan harus dilihat secara detail. Ketiga, dari sisi kemampuan untuk akses modal, kewirausahaan sosial umumnya masih mengandalkan dari dana CSR ataupun dari dana hibah. Berbeda dengan kewirausahaan biasa 
yang umumnya mendapatkan akses modal dari dana pribadi ataupun dana pinjaman dari bank. Keempat, pihak yang terkait (stakeholders). Kewirausahaan biasa mempunyai stakeholder seperti pada umunya usaha bisnis, terdiri dari pemasok, pelanggan ataupun jasa yang digunakan. Tetapi berbeda dengan stakeholder yang ada pada kewirausahaan sosial, seluruh stakeholder pada kewirausahaan biasa masuk didalamnya, dan masih ditambah dengan anggota kelompok yang menjadi sasaran program, serta aparat terkait yang ada di lingkungan masyarakat (Fitria, 2018).

Mengingat kondisi masyarakat yang mengalami kerugian akibat rendahnya harga terong di pasaran. Mahasiswa KPM melaksanakan kegiatan pengabdian masyarakat dengan cara memberdayakan masyarakat Dusun Pondok dalam kegiatan kewirausahaan sosial.

Pemberdayaan ini dilakukan melalui pengorganisasian perempuan. Upaya pengembangan diri secara kelompok dilakukan melalui diskusi dalam upaya pemecahan masalah. Melalui diskusi kelompok dikaji bahwa pemberdayaan merupakan sebuah kebutuhan komunitas dan bukan merupakan kepentingan individu. Dengan komunitas yang kondusif diharapkan akan mampu mengembangkan kemampuan, pengetahuan dan keterampilan serta penguatan diri dalam peningkatan sumberdaya mereka (Hastuti \& Respati, 2009). Kegiatan pelatihan juga dimaksudkan untuk menumbuhkan motivasi berwirausaha (Widiastuti \& Niati, 2018)

Kewirausahaan sosial ini bertujuan untuk menyelesaikan permasalahan yang ada di lingkungan masyarakat tersebut dengan mengadakan pelatihan pembuatan keripik terong. Pembuatan keripik terong diharapkan menjadi produk olahan alternatif masyarakat. Yang nantinya membawa dampak posisitf bagi petani terong sendiri. Keripik terong memiliki nilai ekonomi yang lebih tinggi bila dibandingkan terong tanpa diolah terlebih dahulu (Rumangkit, 2018). Olahan keripik terong juga mampu meningkatkan ekonomi masyarakat melalui bertambahnya pendapatan dari hasil penjualan keripik terong.

\section{METODE PELAKSANAAN}

Kegiatan ini terdiri dari tiga tahap yaitu tahap persiapan, tahap pelaksanaan dan tahap evaluasi. Pada tahap persiapan kegiatannya meliputi observasi di lapangan, konsultasi, perijinan dan koordinasi kepada aparat setempat, pembekalan terhadap mahasiswa, koordinasi dengan anggota ibu-ibu lingkungan masyarakat serta pemilihan lokasi pelatihan. Sementara untuk tahap pelaksanaan merupakan tahap melatih secara langsung ibu-ibu peserta mengenai cara pembuatan keripik terong. Tahap terakhir dari kegiatan ini adalah evaluasi, dimana dialog tim pelatih dengan peserta pelatihan dalam menciptakan produk yang berkualitas.

\section{HASIL DAN PEMBAHASAN}

Bagian ini dapat dijelaskan lebih lanjut dalam tiga komponen yang terdiri dari tahap persiapan, pelaksanaan dan evaluasi.

\section{(1) Persiapan}

Ide pelatihan pembuatan keripik terong ini bermula ketika kelompok mahasiswa melakukan observasi di lingkungan Dusun Pondok, dan ketika akhirnya mahasiswa mendapati potensi adanya lahan salah satu warga yang ditanami terong seperti pada gambar 1 . Mahasiwa pun tertarik dan 
mewawancarai warga setempat. Tetapi terdapat hal yang cukup disayangkan bahwa ternyata masyarakat cenderung enggan menanam terong akibat harga yang tidak stabil. Anggota mahasiswa yang menemukan fenomena tersebut akhirnya berdiskusi dengan anggota kelompok mahasiswa lainnya. Dalam diskusi tersebut muncul ide gagasan untuk membuat olahan alternatif yang sekaligus mampu meningkatakan pendapatan masyarakat itu sendiri. Kemudian mahasiswa peserta melakukan konsultasi kepada dosen terkait ide pelatihan pembuatan keripik terong.

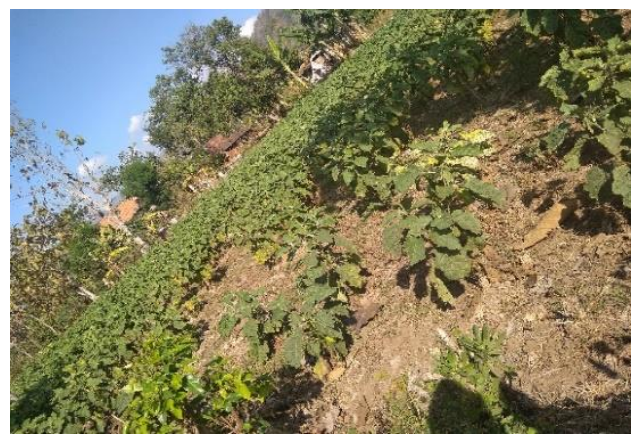

Gambar 1. Lahan petani yang ditanami terong

Setelah melakukan konsultasi kepada dosen, mahasiswa menemui aparat desa terkait untuk meminta ijin kepada kepala desa dan perangkat desa serta RT setempat terkait akan dilaksanakannya pelatihan pembuatan keripik terong. Ide untuk melakukan pelatihan tersebut mendapatkan respon yang positif dari aparat desa terkait.

Setelah berkomunikasi dengan aparat terkait, mahasiswa kemudian melakukan koordinasi terhadap warga sekitar, khususnya ibu-ibu setempat mengenai waktu dan lokasi pelaksanaan kegiatan pelatihan tersebut. awalnya kegiatan akan dilakukan di balai desa, tetapi atas usul ibu-ibu warga sekitar kegiatan dilaksanakan di salah satu rumah warga, dengan alasan kegiatan di balai desa biasanya dilakukan pada siang hari, sehingga sepi peminat, karena kebanyakan masyarakat khususnya ibuibu masih sibuk di rumah ataupun sedang bekerja di sawah. Setelah mendapatkan kesepakatan, kemudian mahasiswa berdiskusi bersama kelompok, pembahasan diskusi antara lain membahas tentang tujuan pelatihan, manfaat dari terong dan potensi pemanfaatan terong serta memastikan dan merinci bahan-bahan dan alat yang harus dipersiapkan, serta berdiskusi terkait teknis pelaksanaan pelatihan.

\section{(2) Pelaksanaan}

Kegiatan pelatihan pembuatan keripik terong dilaksanakan pada tanggal 6 Agustus 2019 bertempat di rumah ibu Simur salah satu warga Dusun Pondok. Seperti yang terlihat pada Gambar 2. ibuibu cukup antusias untuk mengikuti acara pelatihan tersebut walaupun dilaksanakan pada malam hari.

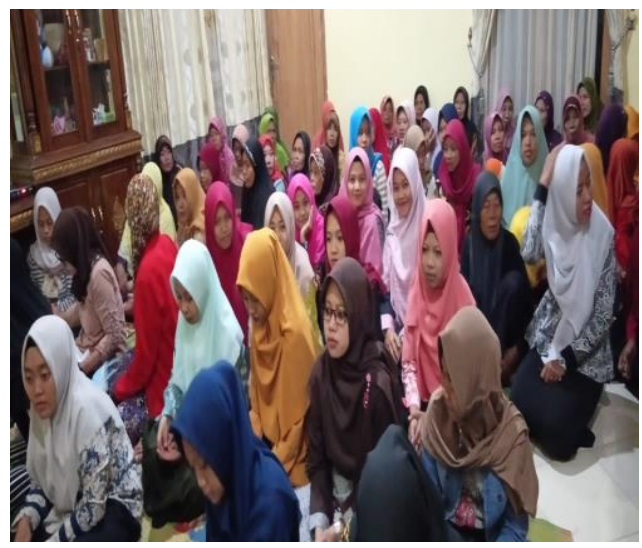

Gambar 2. Peserta antusias mengikuti pelatihan 
Pembukaan acara diawali dengan penjelasan oleh mahasiswa tentang latar belakang maksud dan tujuan diadakannya pelatihan. Kemudian anggota mahasiswa yang lain juga menjelaskan manfaat dan kandungan gizi yang ada pada buah terong, serta penjelasan kepada peserta yang hadir akan peluang ekonomi berupa bertambahnya pendapatan keluarga dengan dibuatnya produk alternatif keripik terong. Mengingat secara umum masyarakat hanya mengetahui bahwa terong hanya dapat digunakan untuk kebutuhan sayur mayur. Akibatnya hasil panen terong yang melimpah menjadikan harga terong menjadi murah dan berdampak pada kerugian para petani.

Penjelasan pun dilanjutkan dengan inisiatif untuk dibentuknya sebuah kelompok masyarakat social entrepreneur (kewirausahaan sosial). Kelompok masyarakat ini bertujuan tidak
Selain itu juga nantinya kelompok masyarakat social entrepreneur diharapkan mampu meningkatkan kebersamaan dan kegotongroyongan di lingkungan masyarakat itu sendiri.

Kegiatan pelatihan kemudian dilanjutkan dengan praktik pembuatan keripik terong. Anggota mempersiapkan peralatan dan bahan-bahan yang diperlukan seperti yang tampak pada Gambar 3. Tahap pelaksanaan berikutnya yakni, membersihkan terong dan memberikan tepung dan bumbu dan bahan-bahan lain agar terong setelah digoreng tetap renyah dan enak dimakan, seperti yang tampak pada Gambar 3. Setelah dilakukan penggorengan, keripik yang sudah jadi ditiriskan agar minyak yang terkandung tidak terlalu banyak. Setelah dirasa cukup dingin keripik diberi tambahan rasa-rasa, diantaranya rasa balado, rasa keju dan rasa yang lain sesuai selera. Hal ini dimaksudkan agar

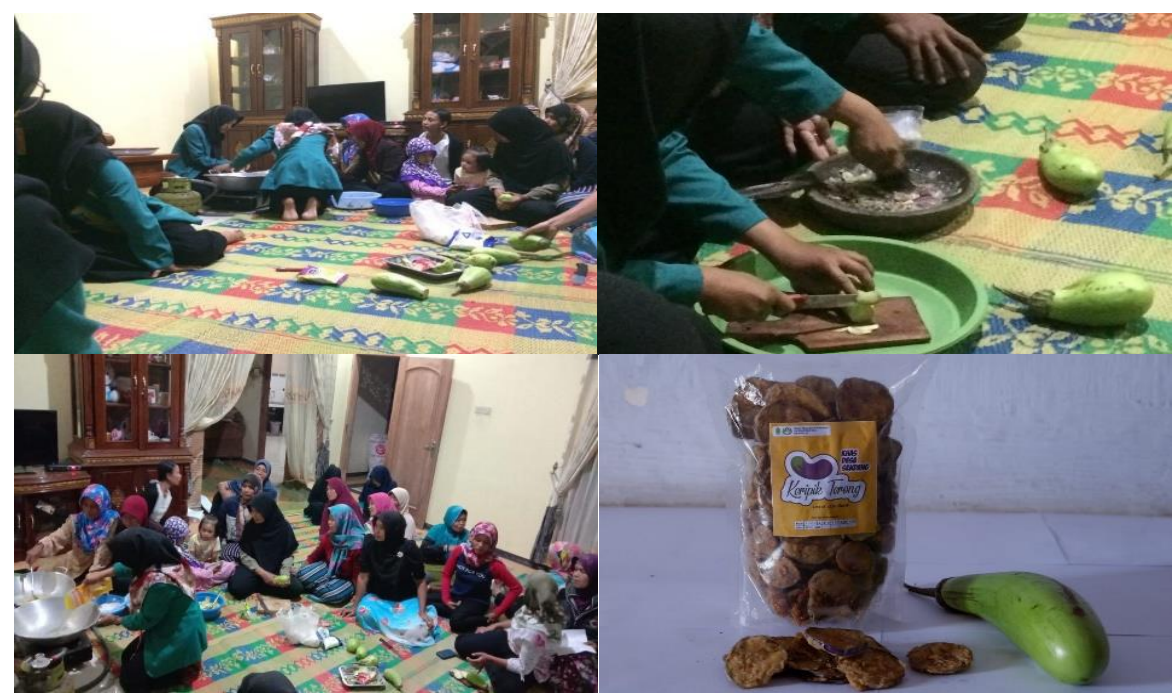

Gambar 3. Pelaksanaan pembuatan keripik terong

hanya meningkatkan perekonomian melalui tambahan pendapatan di masyarakat, tetapi juga mampu menyelesaikan permasalahan kerugian petani akibat harga jual terong rendah. menambah daya tarik dan rasa nikmat saat dikonsumsi. Tahap berikutnya yakni mengemas keripik terong yang sudah jadi seperti tampak pada Gambar 3. Keripik yang sudah dikemas dapat bertahan lama 
dan disisi lain juga menambah daya tarik bila keripik tersebut nanti dipasarkan.

\section{(3) Evaluasi}

Pada tahap evaluasi ini, ibu-ibu dipersilahkan untuk mencoba hasil praktik pembuatan keripik terong. Kemudian mahasiswa melakukan tanya jawab dengan peserta yang hadir. Mahasiswa juga menjelaskan bahwa untuk menarik para konsumen, kemasan keripik sebaiknya didesain semenarik mungkin, diberikan label, masa kadaluarsa dan gambar produk kripik terong yang menjadi ciri khas produk unggulan masyarakat Dusun Pondok. Produk ini pun kedepan sebaiknya di daftarkan di Dinas Kesehatan Kabupaten Ponorogo untuk mendapatkan ijin P-IRT, sehingga mampu meningkatkan daya saing di pasaran.

\section{SIMPULAN}

Masyarakat Dusun Pondok Desa Sendang Kecamatan Jambon Kabupaten Ponorogo dapat diberdayakan dalam meningkatkan pendapatan ekonomi melalui produk keripik terong. Mahasiswa telah mampu bersosialisasi dengan baik dan terlibat aktif dalam pemberdayaan masyarakat, dalam upaya peningkatan perekonomian warga masyarakat melalui pengolahan dan menciptakan produk yang berasal dari hasil pertanian masyarakat sendiri. Telah dihasilkan produk unggulan berupa keripik terong yang dapat menjadi sumber pendapatan tambahan bagi masyarakat Dusun Pondok Desa Sendang Kecamatan Jambon Kabupaten Ponorogo.

\section{Saran}

Saran untuk kegiatan pengabdian berikutnya adalah perlu diadakan pelatihan dan pendampingan terkait stategi pemasaran produk, manajemen usaha yang lebih professional dan pengembangan produk melalui pendaftaran ijin P-IRT kepada Dinas kesehatan Kabupaten Ponorogo.

\section{DAFTAR RUJUKAN}

[Times New Roman 11 bold]

Aswatini, R., Noveria, M., \& Fitranita,

N. F. N. (2008). Konsumsi Sayur Dan

Buah Di Masyarakat Dalam Konteks Pemenuhan Gizi Seimbang. Jurnal Kependudukan Indonesia, 3(2), 97-119.

BPS. (2019). Kabupaten Ponorogo dalam Angka 2019. Ponorogo: Badan Pusat Statistik.

Fitria, A. (2018). Social Entrepreneurship dalam Perspektif Maqashid Al-syariah. Iqtisad, 4(1).

Hastuti, H. M., \& Respati, D. (2009). Model Pemberdayaan Perempuan Miskin Berbasis Pemanfaatan Sumberdaya Perdesaan Upaya Pengentasan Kemiskinan Di Perdesaan. $U N Y$.

Rahmawati, N. D., Dzakiy, M. A., Siska, A., \& Buchori, A. (2018). Pengenalan Entrepreneurship Variasi Olahan Ikan Patin di Grobogan. E-Dimas: Jurnal Pengabdian Kepada Masyarakat, 9(2), 177-184. 
Rumangkit, S. (2018). Peningkatan

Ekonomi Masyarakat Melalui Olahan

Kreatif Dan Branding. Jurnal

Pengabdian UntukMu NegeRI, 2(1), 6265.

Sadono, D. (2008). Pemberdayaan petani: Paradigma baru penyuluhan pertanian di Indonesia. Jurnal Penyuluhan, 4(1).

Tohani, E., Sumarno, S., \& Suryono, Y. (2015). Pendayagunaan Modal Sosial Dalam Pendidikan Kewirausahaan Masyarakat: Studi Pada Program Pendidikan Desa Vokasi. Jurnal Pembangunan Pendidikan: Fondasi Dan Aplikasi, 3(2), 151-166.

Utomo, H. (2015). Menumbuhkan Minat Kewirausahaan Sosial. Among Makarti, 7(14). $\quad$ Retrieved from http://jurnal.stieama.ac.id/index.php/ama /article/view/99

Widiastuti, C. T., \& Niati, A. (2018). Pelatihan Pembuatan Stik Sehat Ikan Kakap untuk Pemberdayaan Ibu Rumah Tangga Kelurahan Mlatiharjo Semarang. E-Dimas: Jurnal Pengabdian Kepada Masyarakat, 9(2), 240-247.

Wiyanto, W. (2019). Pelatihan Pembutan Nugget Jambu Mete bagi IbuIbu PKK Desa Tegalmulyo Kecamatan Kragan Kabupaten Rembang. E-Dimas:
Jurnal Pengabdian Kepada Masyarakat, 10(1), 11-15.

Yaumidin, U. K. (2016). Kewirausahaan Sosial dan Tanggung Jawab Sosial Perusahaan: Tantangan Singergi Multisektor dan Multi-dimensi. Jurnal Ekonomi Dan Pembangunan, 21(1), 103-123. 